\title{
Dobročinnost a princip humanismu
}

\author{
Jaromír Feber \\ Trnavská univerzita v Trnave, SK
}

FEBER, J.: Charity and Principle of Humanism.

Philosophica Critica, vol. 3, 2017, no. 1, ISSN 1339-8970, pp. 3-16.

The article is focused on the problem of humanism. Charity is considered an important aspect of humanism. Advocating charity, the author draws attention to the danger of its absolutisation. Charity is unfair because it goes beyond the principle of giving everyone what he deserves. The author defines the idea of a good society, which should become a higher criterion of moral good.

Key words: Ethics - Charity - Justice - Humanism - Good society

\section{Úvod}

Tradičně je k univerzálním etickým principům řazen princip humanismu. Je explicitně vyjádřen i ve většině dnešních učebnic etiky. Formuluje jej například J. Vajda: „Princip humanismu... představuje lásku člověka k člověku“ (Vajda 1995, 50), ze které vyplývá „vyzdvižení hodnoty člověka, jeho života, do čela hodnotové pyramidy“ (Tamtéž). K principu humanismu se hlásí rovněž V. Gluchman, když tvrdí: „Dobrem, v souladu s kritériem mravnosti a nejvyšším mravním principem, je vše to, co naplňuje život člověka radostí, štěstím, pohodou a pokojem, sociální jistotou, pocitem bezpečí a jistoty, spokojeností. Dobro je vlastně to, co přispívá k naplňování důstojnosti člověka, k jeho uplatnění se ve společnosti, povolání, rodině, které uspokojuje jeho sociální, kulturní, duchovní, ekonomické potřeby atd. i potřeby jiných lidí v jeho okolí, ale za předpokladu humánnosti a zákonnosti tohoto jednání a také za předpokladu teoreticky rovné šance pro každého“ (Gluchman 1994, 105). Hlásíme se k humanistické tradici, která je rozvíjena jako program uvědomělého úsilí o další rozvoj člověka.

Vycházíme ze skutečnosti, že svět, ve kterém žijeme, je lidským světem, a právě proto se přikláníme $\mathrm{k}$ názoru, že bychom měli jako absolutní hodnotu tvořící základ univerzálního morálního prostoru prosazovat hodnotu Člověka. Tato hodnotová orientace nachází svou konkretizaci v normativním principu humanismu, jehož smysl lze obsahově vyjádřit ve třech základních požadavcích: 1) Vytváření společenských podmínek umožňujících rozvoj lidské osobnosti a její seberealizaci. 2) Garantování základních práv člověka jako obecná podmínka individuální 
existence. 3) Dobročinnost jako podpora a pomoc druhým. Ve svém textu se zaměřím na dobročinnost, která je obecně považována za součást humánního vztahu k lidem. Teoretická analýza však zároveň odhaluje jistou problematičnost začlenění dobročinnosti jako organické součásti principu humanismu. Především narážíme na problém logické konzistence jednotlivých dílčích aspektů humanismu. Ukazuje se, že dobročinnost nelze absolutizovat. Pozitivní řešení problému dobročinnosti spatřujeme ve stanovení určitých mezí, v rámci kterých lze dobročinnost považovat za pozitivní hodnotu.

Metodologicky se hlásíme k tradici deontologické etiky inspirované I. Kantem a svůj text pojímáme jako aplikaci třetí formulace kategorického imperativu na konkrétní etické problémy spojené právě se začleněním dobročinnosti do principu humanismu. Zásadu, že každá rozumná bytost musí jednat tak, „jakoby prostřednictvím svých maxim byla vždy zákonodárným členem všeobecné říše účelü“ (Kant 2004, 67), interpretujeme jako požadavek podílet se na tvorbě univerzálního morálního prostoru, kterým je pro nás idea dobré společnosti. Moralitu dílčích hodnot a zásad tak posuzujeme z hlediska jejich možného začlenění do ideálního společenského celku.

\section{Altruismus}

V morálních základech dobročinnosti leží hodnota „altruismu“. Altruismus lze vymezit jako etický princip, který předpisuje nezištné jednání zaměřené na uspokojení zájmů jiných lidí. Termín „altruismus“ byl zaveden A. Comtem k označení postoje protikladného k egoismu. Oprávněně je mnohými moralisty (především J. Benthamem, I. Kantem, A. Schopenhauerem či W. Jamesem) interpretován jako historický typ morálky překonávající egoistické typy morálky (jako napřr. eudaimonismus, hedonismus, asketismus či perfekcionismus), které se primárně zaměřují na život jednotlivce (Hodovský 1992, 37 - 51). Altruismus kultivuje vědomí nutné sounáležitosti a ohrazuje se vůči egoismu, který nedoceňuje společenskou povahu lidského života. V morálním vědomí je egoismus oprávněně odsuzován jako projev parazitizmu, protože společnost umožňuje život člověka tím, že vytváří pro jeho život nutné podmínky, a egoista je sice využívá, ale odmítá se na jejich kultivaci přiměřeně podílet. Egoismus je z obecného hlediska nerozumný, protože kdyby ve společnosti každý prosazoval jen své zájmy, společnost jako celek by přestala fungovat a v konečném důsledku by ani jednotlivci své osobní zájmy nemohli uspokojovat. Narážíme na známý paradox ,absolutního egoismu', který ukazuje, že egoismus ruší sám sebe, protože možnost uspokojení vlastních zájmů a potřeb závisí na fungování společenského celku. Ale aby mohl společenský celek fungovat, musí jedinci své ego v zájmu celku omezit. 
Ve 20. století byla problematika spojená s altruismem rozvíjená především v kontextu zkoumání různých forem prosociálního jednání či solidarity a vzájemné pomoci. Nicméně je nutné upozornit, že střet „altruismus versus egoismus“ nevyjadřuje rozpor „soukromého a společenského zájmu“, ale „mého a cizího zájmu“. Z vymezení pojmu „altruismus“ vyplývá, že se nejedná o podporu obecného zájmu, ale zájmu druhého člověka. Altruizmus se odlišuje od kolektivizmu, který podřizuje jedince zájmům skupiny.

$\mathrm{Z}$ vymezení altruismu vyplývá řada problému, na některé $\mathrm{z}$ nichž je vhodné upozornit. Především kdo a jak má posoudit zájmy druhého, zejména za situace, kdy druhý není schopen posoudit svůj skutečný zájem sám, tj. není suverénem svého života. Jak posoudit způsob aplikování altruismu vůči druhému, který je zlým člověkem, tj. porušuje normy chování, nerespektuje závazná pravidla, chová se nečestně, činí nespravedlnost, atd. Jak posoudit podle jakých kritérií distribuovat materiální pomoc za situace, kdy společenské zdroje jsou omezené. Jak posoudit, kdy se pomoc stává „medvědí“, tzn. že více škodí než prospívá. Bezbřehý altruismus jedince nemotivuje, protože spoléhání se na vnější pomoc brání vlastnímu usilování. Bezbřehý altruismus jedince demoralizuje, protože nezasloužená pomoc popírá princip spravedlnosti. Bezbřehý altruizmus se dostává do vnitřních rozporů i proto, že ve společensky provázaném světě upřednostnění zájmů jednoho vede k poškození jiného. (Budeme-li například nezištně pomáhat tím, že budeme rozdávat chleba zadarmo, poškodíme prodejce, budeme-li ubytovávat zadarmo, poškodíme pronajímatele bytů, atd.)

To nás přivádí k závěru, že absolutní altruismus je stejně nerozumný, jako i absolutní egoismus. Oba nemohou nabýt statusu univerzální morální hodnoty, protože by neprošly testem obecnosti, který v duchu Kantovy etiky považujeme za univerzální kritérium odlišující správné od nesprávného.

Altruismus se vztahuje na potřebné, tj. na lidi, jejichž život neprobíhá normálně, protože nedosahuje té kvality, která je v dané společnosti považována za standardní. Ti se pak stávají předmětem dobročinnosti. Účelem dobročinnosti není pomoci všem lidem univerzálně, ale jen takovým, kteří se bez pomoci neobejdou. Takto realizovaná pomoc je však ve zřejmém rozporu s takovými univerzálními hodnotami jako je rovnost, spravedlnost, a také svoboda, protože potřebný druhý se stává objektem vnějšího působení a ztrácí autonomii.

Pro výstavbu etiky je zásadní si uvědomit, že lidské jednání má v posledku vždy teleologickou orientaci, protože vždy slouží k realizaci určitých cílů. Každá morálka má proto svým způsobem instrumentální charakter. Slouží k realizaci určitých hodnot, které vymezujeme jako žádoucí cíle našeho jednání. Absolutním morálním požadavkem, který na člověka klademe, je požadavek podílet se na tvorbě lepšího světa. Svět, ve kterém žijeme a který jsme schopni žádoucím způsobem dotvářet je společnost, a proto etické principy formulované a zdůvodňované etikou by měly vyjadřovat ideální stav společnosti. Jejich účelem je vytvářet stabilní 
univerzální morální základ společenského života. Účelem etických principů je stanovovat, jak by to ve společnosti mělo být, aby se život v ní přiblížil k určitému morálnímu ideálu jako bezpodmínečné cílové hodnotě.

Za inspirativní pro stanovení absolutní cílové hodnoty považujeme etiku Kanta, který ji vymezuje ve druhé formulaci kategorického imperativu: „jednej tak, abys používal lidství jak ve své osobě, tak i v osobě každého druhého vždy zároveň jako účel a nikdy pouze jako prostředek" (Kant 2004, 57). Ve třetí formulaci kategorického imperativu z této absolutní hodnoty Kant následně odvozuje, že „každá rozumná bytost jako účel sám o sobě musí ve vtahu ke všem zákonům, jimiž by mohla být podřízena, mít možnost považovat se zároveň za zákonodárnou, protože právě tato přiměřenost jejích maxim pro obecné zákonodárství vyznačuje ji jako účel sám o sobě, a dále, její výsadní důstojnost (prerogativa) oproti všem přírodním bytostem nese s sebou, že musí pojímat své maximy z hlediska sebe samé, ale zároveň z hlediska každé druhé rozumné bytosti jako bytosti zákonodárné (ta se proto také nazývá osobou). Takovým způsobem je nyní možný svět rozumných bytostí (mundus inteligibilis) jako říše účelů, a to na základě zákonodárství všech osob jako členů“ (Kant 1996, 67). Scruton v této souvislosti upozorňuje na důležitý aspekt třetí formulace: „Tento třetí imperativ naznačuje, že každá spekulace o cílech je také postulováním ideálního světa, v němž jsou věci, jak by měly být... V této ř́ší není nic v rozporu s rozumem a rozumná bytost je subjektem, ale i vládcem zákona, který zde dostává“ (Scruton 1996, 86).

Když začleňujeme dobročinnost do kategorie morálního dobra, měli bychom si zároveň uvědomit, že ji sice postulujeme jako nedílnou součást principu humanis$\mathrm{mu}$, ale ona zřejmě překračuje hranice nutné morální povinnosti. V jistém protikladu ke Kantově perspektivě rovného zacházení se staví idea asymetrického morálního závazku vůči jinému. I když dobročinnost nelze absolutizovat, má v nedokonalém lidském světě své místo. Není vždy absolutně povinná, nicméně její uplatňování je jistě žádoucím doplněním toho etického minima, které vymezuje etika povinnosti.

\section{Dobročinnost}

Dobročinnost lze definovat jako činnost, prostřednictvím které se dílčí zdroje dobrovolně a nezištně distribuují jejich vlastníky na podporu potřebným, na řešení společenských problémů a také na potřeby zlepšování podmínek společenského života. Lidé potřebující pomoc nejsou nutně jen ti, kteří žijí v bídě, ale i ti, kteří pocit'ují nedostatek v doplňkových prostředcích, které by jim umožnili realizovat jejich společensky významné (např. profesionální) zájmy. Dílčími zdroji mohou být nejen materiální a finanční prostředky, ale i schopnosti a energie. 
Dobročinnost je často nepřesně chápána jako poskytování almužny, a opravdu z hlediska motivů a hodnotových základu mají mnoho společného, nicméně při vymezení dobročinnosti jako určité společenské praxe je vhodné ji od almužny odlišovat. Almužna představuje soukromý, spíše výjimečný počin, který reaguje na bezprostřední nouzi mající za cíl zmírnit její dopady na život strádajícího člověka. Naopak dobročinnost má spíše neosobní charakter, překračuje hranice příbuzenských a přátelských vztahů, a i v př́ípadě, že je zaměřena na konkrétního př́ijemce, má v konečném důsledku řešit společensky významnější problémy. Není zaměřena výhradně jen na pomoc vyloženě strádajícím lidem, ale zahrnuje všechny, kteří pomoc z různých důvodů potřebují. Dobročinnost má vesměs organizovaný charakter a uskutečňuje se plánovitě jako realizace speciálně rozpracovaných programů. Nejen činnost v oblasti sociální práce, ale i př́íspěvky na chod univerzit, muzeí, nemocnic, kostelů, na ekologické projekty atd., stejně jako vytváření institucí, které se zavazují, že budou racionálně rozdělovat získané prostředky, řadíme všechny do kategorie dobročinnosti. Na rozdíl od humanitární pomoci, která řeší aktuální pohromy a má neodkladný a imperativní charakter, je dobročinnost závislá na dobré vůli pomoct nejen v katastrofálních případech, ale i v těch, ve kterých se jedná o určité žádoucí zlepšení určitých např. pracovních či obecně životních podmínek.

Dobročinnost je sice považována za součást humánního vztahu k ostatním lidem, ale požadavek univerzalizace dobročinnosti by se dostal do rozporu s nutnou konstitutivní morální zásadou tvorby společenského celku, kterou je spravedlnost. Dobročinnost není spravedlivá, protože morální závazek pomoci překračuje zásadu dát každému, co mu patří. (Klasická definice spravedlnosti, které se přidržujeme je Justiniánova: „spravedlnost je stálá a neustávající vůle dát každému, co mu patří (Blackwellova encyklopedie politického myšlení 1995, 494).)1 ${ }^{1}$

\section{Dobročinnost a spravedlnost}

Spravedlnost se řídí logikou ekvivalence - míra odměny nebo trestu má odpovídat míře zapř́činěného dobra či zapříčiněného zla. Naopak dobročinnost se řídí logikou excesu, tj. logikou nadměrnosti. Princip humanismu spojující požadavek spravedlivého a rovného zacházení s požadavkem nezištné pomoci se tak snaží propojit dvě různé logiky, logiku ekvivalence a logiku excesu, které odlišně regulují lidské jednání.

1 Bylo by možné namítnout, že existují koncepce, které se pokouší dobročinnost se spravedlností propojit. Např. podle sv. Augustina je skutečně spravedlivý jen ten, kdo slouží Bohu a svému bližnímu. Nicméně se domnívám, že podobná interpretace je možná jen v rámci náboženských koncepcí, ve kterých jsou morální kvality člověka (a tedy i spravedlnost) interpretovány jako soulad s Bohem a jeho přikázáními. 
V morálním prostoru se takto střetávají dvě etiky ve smyslu dvou odlišných způsobů racionalizace a zdůvodnění morálního jednání: etika spravedlnosti a etika lásky. (Přidržujeme se výstižné definice lásky, jejímž autorem je Tomáš Akvinský: „Milovat znamená chtít něčí dobro“ (Peschke 2004, 187).)

Láska jako morální ctnost znamená usilování o dobro člověka. Přičemž jako každá ctnost je tím hodnotnější, čím méně je motivována jen citovou či dokonce erotickou náklonností, ale výhradně dobrou vůlí, jejíž prosazení vyžaduje vynaložení určitého nesobeckého úsilí. Křest’anské „Miluj svého bližního jako sám sebe!“ (Mk 12, 31) přikazuje konat jiným lidem dobro nezávisle na tom, jestli si to zaslouží či nikoli. Etika lásky akcentuje neinstrumentální hodnotu druhého člověka, nabádá k vynaložení úsilí na překonání vlastní sobeckosti a potlačení snahy o prosazování jen vlastních zájmů. Avšak upřednostnění druhého musí znát míru, protože její absolutizace by vedla k destrukci společenského celku. Jedině princip spravedlnosti je schopen náležitě motivovat a regulovat lidské jednání, které se vždy potýká s určitou mírou nedostatku vyžadující spravedlivou distribuci statků, stejně jako se vždy potýká s určitou mírou nedokonalosti lidských charakterů předpokládající spravedlivé soudnictví.

Láska k druhému jako součást principu humanismu v té podobě, jak je inspirována křest'anskou tradicí, obsahuje řadu požadavků, k nimž patří především: 1) Odmítání použití násilí ve vztahu k druhému. 2) Službu jako nesobeckou snahu o to, aby druzí nestrádali a mohli zlepšovat uspokojování svých potřeb. 3) Odpouštění zla, které tito druzí napáchali. Nicméně je nutné mít na paměti, že abstraktní absolutizací lásky k bližnímu by se snižovala konkrétní individuální hodnota jednotlivce, protože v podobě neekvivalentního imperativu vybízí k nemotivovanému upřednostnění libovolného druhého, které však znamená lhostejnost k jeho vlastní individuální morální kvalitě. Milovat každého tak paradoxálně znamená nemilovat nikoho konkrétního.

Absolutizace křest'anské lásky obsahuje i další paradox. Požadavek lásky ke všem lidem bez výjimky znamená milovat i zlé lidi. Dobrý člověk tak stojí před problémem: prosazování dobra předpokládá mimo jiné aktivní úsilí o potlačování zla, ale zároveň v duchu lásky k člověku se mají nositelé zla milovat, tzn., nemají se k ničemu nutit a naopak se jim má sloužit. Řešení tohoto paradoxu předpokládá oddělení zla od jeho nositele, protože jen tak lze milovat hř́šníka a zároveň nenávidět hřích. Domníváme se však, že v intencích humanistické etiky, o kterou usilujeme, to není možné, protože výhradně lidská individuální osobnost může být původcem dobra či zla. Právě to je smyslem mravní svobody, která implikuje mravní odpovědnost tvořící nutný základ tvorby morálního světa.

Jakákoli tvorba má smysl jen v nedokonalém světě, protože v dokonalém světě není potřeba nic měnit, vše již je k dispozici a není třeba nic vytvářet. Hybatelem tvorby je jistý rozpor mezi subjektivními požadavky a objektivním stavem. Obdobně tvorba morálního světa je založena na jeho faktické nedokonalosti. V mo- 
rálně nedokonalém světě musíme vycházet s individuální odpovědnosti za činěné dobro a zlo, protože jinak ztratíme měřítko jak konkrétní zlo potlačovat a naopak konkrétní dobro prosazovat. $\mathrm{K}$ faktické nedokonalosti světa především patří nedokonalost jeho tvůrců, tj. konkrétních lidí. Neekvivalentní láska ke každému jen stěží přiměje všechny k tomu, aby neparazitovali na společném úsilí, sobecky neškodili ostatním a naopak se připojili k plnění svých povinností.

Láska k bližnímu vyžaduje soustředit pozornost na druhého, na zlepšení jeho života a zmírnění jeho strádání. To však může vést k určitému zanedbávání sebe sama. Člověk by však měl dbát svých povinností i vůči sobě, protože jen rozvinuté osobnosti se stávají plnohodnotnou součástí morálního světa, a proto je jejich povinností o svůj vlastní rozvoj usilovat. Láska k bližnímu může částečně bránit tomuto základnímu dobru a dokonce maskovat osobnostní slabost a impotenci. $\mathrm{V}$ této souvislosti lze připomenout myšlenku F. Nietzscheho o křest’anské lásce jako produktu resentimentu, o její nesmyslnosti pro lidi, kteří se ještě nenaučili skutečně milovat sama sebe (Petrucijová 2010, 62).

Zásadním argumentem proti absolutizaci „lásky“ však zůstává, že by mohla negovat normy, které jsou nutnou součástí morálního světa. Známý psycholog Lawrence Kohlberg v souvislosti se zkoumáním šesti stádií morálního rozvoje osobnosti analyzoval dilema muže, který nemá dostatek peněz, aby koupil lék, který by zachránil jeho ženu umírající na rakovinu, a proto zvažuje, nemá-li tento lék ukrást (Kohlberg 1981).

Krádež jakkoli motivovaná není správná, protože by se nemohla stát univerzální morální normou. Naopak nekrást je oprávněné považovat za ctnost právě proto, že vyžaduje úsilí vedoucí k potlačení vlastního prospěchu (i vlastních náklonností). Požadavek nekrást je univerzálním společenským imperativem proto, že jeho popření by vedlo $\mathrm{k}$ destrukci společnosti.

Je ovšem zároveň pravdou, že přinutit se nekrást ve prospěch záchrany milované osoby je obzvláště těžké. Činy, které vyžadují sebeobětování řadíme do kategorie morálního hrdinství. Morální hrdinství je provázeno určitou necitelností vůči sobě v případě sebeobětování, či vůči jiným v př́ípadě obětování druhých. Ona necitelnost je zdůvodňována a ospravedlňována vyššími etickými principy, které jsme povinni prosazovat. Vůči podobné zásadovosti bychom asi měli namítnout, že necitelnost zřejmě není součástí lidskosti, kterou hájíme v podobě principu humanismu.

Není obvykle nutné, aby morální kvality dobrého člověka dosahovaly úrovně morálního hrdinství. Je naopak určitě správné, když morální selhání za situace, které hrdinství vyžaduje, nebylo odsuzováno přiliš přísně. Určitě není povinné být hrdinou, ale to nemění nic na skutečnosti, že lidský soucit neznamená, že bychom na jeho základě měli běžně popírat univerzální hodnoty, ale jen to, že jsme někdy ochotni, ze soucitu, netrvat na jejich přísném a nekompromisním prosazování. 
Bylo by z morálního hlediska, tj. z hlediska ideálního fungování společenského celku, určitě lepší požádat vlastníka potřebných zdrojů ( $\mathrm{v}$ našem případě potřebných léků), aby je formou dobročinnosti poskytl tomu, který je nutně potřebuje, ale není schopen si je opatřit správným způsobem. Dobrý člověk by podobnou dobročinnost neměl odmítnout. Krádež sice nemůže být součástí morálního společenského řádu, ale lidské utrpení k němu rovněž nepatří. Krádež je někdy možná menším zlem, než absence soucitu a neochota pomoct, ale pořád jde o zlo, které bychom se měli snažit v ideálním světě potlačovat.

Obecně není dobročinnost bezpodmínečně povinná. Kategorizujeme-li morální normy na př́kazy (imperativy), zákazy (tabu) a povolení, ve kterých následně formulujeme jednak to, co je z morálního hlediska nutné a co tedy musíme jako dobří lidé dělat vždy (imperativy), co je z morálního hlediska nemožné a co jako dobří lidé nesmíme dělat nikdy (tabu), a co je z morálního hlediska možné (povolení), pak dobročinnost nelze celkově řadit do kategorie morální nutnosti, ale jen do kategorie morální možnosti. Je jistě dobré pomáhat druhým, ale jen ve výjimečných případech spadá dobročinnosti do kategorie morální nutnosti.

Nicméně široce pojatý princip humanismu, který se snažíme obhajovat, jistě nelze redukovat jen na dodržování absolutně závazného etického minima vymezeného imperativy a tabu, ale měl by obsahovat i prvek morální možnosti, která se realizuje formou dobročinnosti. Dobročinnost je motivována snahou zlepšit tíživou situaci, do které se druhý člověk může dostat.

Z morálního hlediska však dobročinnost nejenže nevyžaduje úplné sebeobětování, ale dokonce to není ani žádoucí, protože v př́ípadě, že by její poskytovatel úplně vyčerpal své síly a bohatství, nemohl by se nakonec postarat ani sám o sebe a potřeboval by pomoc. Na což oprávněně upozorňuje v Metafyzice mravů i I. Kant. Dobročinnost by neměla úplně popírat logiku ekvivalence, protože závazek vůči druhým by měl být v rovnováze k závazku vůči sobě (Kant 1996). ${ }^{2}$

Dobročinnost se především může omezit na poskytování druhým určitého nadbytku zdrojů, sil či času. Není rovněž v rozporu s dobročinností, že obsahuje prvek výběru, kdy je na zvážení poskytovatele dobročinnosti, kdy a v jaké míře ji chce poskytnout. Také odpor ze strany př́ijemce dobročinnosti může zbavit poskytovatele morálního závazku ji uskutečňovat.

\footnotetext{
2 Podobné tvrzení neznamená, že si neceníme těch, kteří se ve prospěch druhých obětovali. Nicméně se nedomníváme, že projevy morálního hrdinství by měly být pojímány jako norma lidského jednání, ale vždy jen jako výjimečný počin, který by ale v dobře fungující společnosti, o kterou bychom měli usilovat, neměl být nutný. Morální hrdina se nespokojuje jen s dodržováním morálních povinností a výrazně je překračuje. Supererogativní jednání je především v křest'anství považováno za sice obtížnou, ale spolehlivou cestou ke spáse a bylo vymezováno především jako překračování toho morálního minima, které stanovuje desatero (Heyd 1982, 16 - 26).
} 
Je zároveň pravdou, že je někdy oprávněné dobročinnost přesunout z kategorie morální možnosti do kategorie morální nutnosti, kdy se její poskytování stává povinným. V určitých př́padech je totiž neposkytnutí pomoci totožné s přičiněním újmy. Tehdy je morálně oprávněné dokonce vyžadovat poskytování pomoci i právní cestou (Fabre 2004, 129 - 145). V trestním právu se často formulují sankce vůči těm, kteří v kritické situaci neposkytnou pomoc.

Hlavním smyslem dobročinnosti je starost a péče o druhé. Znamená praxi všestranné podpory, která zahrnuje vytváření podmínek zlepšování úrovně života a plnohodnotné seberealizace. Přičemž skutečná dobročinnosti by měla zahrnovat i prvek empatického spoluprožívání, ve kterém se naplňuje potřeba „být spolu“, nezůstat v těžké situaci osamocen. Starostlivost a péče má vytvářet situaci určité jednoty, kdy je potřebnému dáno na vědomí, že někam patří, že je plnohodnotnou součástí společnosti.

Ve své protikladnosti k logice ekvivalence má starostlivost a péče mnoho společného s milosrdnou láskou. Nicméně mezi etikou milosrdné lásky a etikou starostlivé péče existují rozdíly, na které upozornil např́klad N. Noddings. (Noddings 1984, 89). Především se liší svým emocionálním nábojem. Určitá míra citlivosti, která by měla provázet péči, nemusí dosahovat stupně hlubokého láskyplného citu. $V$ duchu kantovské etiky povinnosti by se tím dokonce snižovala morální kvalita péče, protože by byla motivována náklonností, a ne úctou k etickému zákonu. Navíc etika milosrdné lásky zahrnuje každého člověka, ale etika starostlivé péče vychází z nemožnosti uskutečnit natolik obsáhlý normativní program, protože nelze pečovat o všechny. Všechny sice lze abstraktně milovat, ale reálná starostlivost a péče má své hranice, které je sice správné neustále rozšiřovat, avšak musí být zachovány, protože jinak se zmenšují možnosti je účinně realizovat.

\section{Dobrá společnost}

Dobročinnost $v$ jakékoli podobě se někdy stává předmětem částečně oprávněné kritiky. Pod rouškou dobročinnosti se někdy realizují sobecké zájmy těch, kteří na dobročinnost přispívají. Nelze rovněž přehlížet kritiku dobročinnosti z pozic utilitarismu. Argumenty se v takovém př́ípadě opírají o analýzu sociálních důsledků dobročinnosti, je zpochybňována její efektivita a je připomínána její zřejmá nespravedlnost. Nicméně i kdybychom se chtěli pohybovat mimo diskurz autonomně pojaté morálky a přistoupili na heteronomní pojetí morálky jako jen prostředku řešení mimo-morálních účelů, které je charakteristické pro utilitarismus, tak i v takovém př́padě bychom mohli nabídnout řadu protiargumentů, které sociální význam dobročinnosti zdůvodňují. Podpora lidí, kteří se dostali do obtíží, přispívá k zachování a reprodukci celku společnosti, protože vyhrocený konflikt mezi 
bohatými a chudými narušuje nutnou společenskou jednotu a vede k rozvratu. Dobročinnost se stává důležitým prostředkem snižování společenského napětí mezi bohatými a chudými i tím, že částečně kompenzuje nespravedlnosti v distribuci společenského bohatství. Dobročinnost plní i potenciálně významnější funkci. Podpora perspektivních iniciativ napomáhá budoucímu rozvoji společnosti. V podobné utilitaristické perspektivě však není žádoucí, aby byla podporována lenost a pasivita. V souladu s principem užitečnosti již J. S. Mill formuloval zásadu, podle které by se ten, který se spoléhá na pomoc, neměl nacházet v lepší situaci než ten, který je schopen se bez ní obejít. Když k tomu dochází, není pomoc správná, protože dobročinnost by neměla podkopávat individuální pracovitost a úsilí o zajištění soběstačnosti (Mill 1843,123).

Přínos utilitaristické kritiky dobročinnosti lze spatřovat v tom, že připravila intelektuální půdu pro změnu priorit v chápání dobročinnosti. Dobročinnost začíná být ve 20. století chápána stále více jako prostředek zlepšování společnosti. Dobročinnost nemá jen bezprostředně uspokojit nejnutnější potřeby strádajících, ale má především vytvořit podmínky pro to, aby si potřební mohli postupně sami zlepšovat své postavení a svou životní úroveň. Široce pojatá dobročinnost se má stát prostředkem společenského pokroku a má nabídnout reálnou alternativu ke snahám o revoluční změnu společenského systému.

Když jako absolutní hodnotu postulujeme v souladu s principem humanismu hodnotu člověka, pak zároveň musíme vycházet ze společenské podstaty člověka. Společnost je nutnou podmínkou lidského života, jedině ona je schopna vytvářet pro život člověka nezbytné podmínky. Proto když tvrdíme, že základním morálním požadavkem, který na člověka klademe, je podílet se na tvorbě lepšího světa, pak tím především máme na mysli, že by se měl podílet na tvorbě lepší společnosti, tj. toho prostoru, ve kterém život člověka bezprostředně probíhá a který určuje jeho kvalitu a úroveň.

Společenským ideálem, který v současnosti dominuje v našem západním kulturním prostoru, je idea demokracie, přesněji liberální demokracie, protože právě v liberální demokracii byl k demokracii jako vládnutí, které probíhá se souhlasem lidu (prakticky vyjadřovaného volebním aktem), explicitně přiřazen i hodnotový rozměr (Podrobněji: Feber 2015, 4 - 17). Liberální demokracie je založena především na hodnotách spravedlnosti, svobody, rovnosti a solidarity, které se její protagonisté zavazují prosazovat. Protože mají stěžejní význam pro fungování současné liberální demokracie, stávají se tyto hodnoty i hlavním předmětem analýzy uskutečňované současnou politickou filozofíí, která na teoretické úrovni hodnotové základy společnosti tematizuje (Swift 2005, 15). Úvahy o hodnotách jsou důležité, protože právě ony se v liberální demokracii stávají základní součástí legitimizace moci. Ze závazku prosazovat liberální hodnoty odvozuje náš politický systém svou legitimitu. 
Idea demokracie se v současné západní společnosti stává symbolickým vyjádřením souhrnu těch hodnot, které by měly tvořit konstitutivní základ budování ideální společnosti. Aby však idea demokracie mohla sloužit jako hodnotový cíl našeho společenského snažení, měla by být vymezována nejen jako deskriptivní pojem, ale důsledně jako idea, tj. utopie v původním významu tohoto slova jako označení místa, které ještě není. Jedině tak může idea plnit funkci orientačního bodu, který motivuje k neustálému tvůrčímu zdokonalování daného stavu společnosti. Zároveň jen jako nikdy zcela nerealizovaný ideál může idea demokracie sloužit jako nadčasové hodnotové kritérium posuzování dobových společenských poměrů.

Jsme-li zastánci humanistické etiky, tzn. etiky, která za nejvyšší hodnotu, tj. hodnotu zdůvodňující v konečném důsledku morálnost jakéhokoli jednání, postuluje plnohodnotný a důstojný lidský život, pak ideální neboli „dobrá společnost" je taková, která takový život umožňuje. Plnohodnotný je život tehdy, když společnost nabízí dostatečnou životní úroveň, a vytváří tak podmínky pro individuální seberealizaci. Mírou životní úrovně je rozvinutí a stupeň uspokojování materiálních a duchovních potřeb, které je podmíněno produktivitou společnosti, tzn. schopností společnosti produkovat materiální a duchovní hodnoty v co nejvyšší kvantitě a kvalitě. Důstojný je život tehdy, když probíhá ve společnosti, která je v pořádku z morálního hlediska, kdy je celková morální kvalita společnosti na dostatečné úrovni.

Definujeme-li společnost jako „celek, jehož uspořádání lze změnit politickým jednáním a za jehož stav člověk nese spoluodpovědnost“ (Gunther 1997, 19), pak musíme nejen jednotlivce, ale i společnost považovat za morální kategorii, protože i ona může působit jak dobře, tak zle, a proto se následně stává předmětem morálního posouzení. A pojímáme-li dále společnost jako organizovaný celek konstituovaný systémem kulturních podmínek, z nichž jsou z organizačního hlediska zásadní společenské instituce jako určité lidmi vytvářené formy organizace společenského života, pak právě ony se stávají hlavním předmětem morálky.

Klademe-li si otázku, jaká by měla být společnost, pak se především ptáme, jaké morální kvality by měly dosahovat instituce, které ji utvářejí. A vyjdeme-li z jednoho z nejproslulejších tvrzení J. Rawlse, že „spravedlnost je základní ctností společenských institucí (Rawls 1971), pak právě na spravedlnost se ptáme v prvé řadě. Naplnění této ctnosti a dalších, které s ní přímo souvisí, se stává kritériem morální kvality společnosti.

Můžeme shrnout, že dobrá společnost je taková, která: 1) plní svůj účel tím, že umožňuje plnohodnotný život jednotlivce (utilitární hledisko heteronomní morálky) a je 2) spravedlivá (hledisko autonomní morálky). Z vymezení „dobré společnosti“ odvozujeme kritéria pokroku, kterými jsou především: 1) životní úroveň a 2) úroveň spravedlnosti. Nalezená obecná kritéria dobré společnosti umožňují hodnotit aktuální stav společnosti. 
V souladu s principem humanismu by však hledisko autonomní morálky mělo být zastoupeno nejen povinností zajistit spravedlnost, ale navíc povinností zajistit určitou míru životní úrovně. V dobré společnosti, v souladu s principem humanismu, přísluší určitá (historicky podmíněná) míra úrovně života každému člověku jen z toho důvodu, že je součástí příslušné společnosti, a to nezávisle na individuálních zásluhách. Úlohou dobročinnosti je zajistit, aby především znevýhodněné sociální skupiny určité přiměřené životní úrovně skutečně dosáhly. Chovat se lidsky (tj. v souladu s principem humanismu) jistě předpokládá určitou míru dobročinnosti, která znamená pomáhat, starat se a pečovat o ostatní. Zastáváme dokonce názor, že je oprávněné široce pojatý princip humanismu ve společnosti institucionalizovat.

\section{Závěr}

Chceme-li dobročinnost obhajovat jako správný morální požadavek, musíme zároveň stanovit její meze. V určitých mezích je žádoucí, protože tvoří nutnou součást široce pojaté lidskosti. Zároveň by však dobročinnost neměla úplně popírat princip spravedlnosti tvořící nutný morální základ společenského života. V souladu s kategorizací morálních norem by sice morální prostor dobročinnosti měl spadat především do kategorie morálně možného, ale určitá míra dobročinnosti zajištujující určitý minimální životní standard, pod úroveň kterého by se v dobré společnosti neměl dostat žádný člověk, je oprávněné zařadit do kategorie morálně nutného.

Je skutečností, že vymezení morálně možného a nutného se mění, protože je závislé jednak na objektivních možnostech dané společnosti, ale také na subjektivní vůli podělit se o bohatství s těmi, kteří to potřebují. Na jedné straně je z morálního hlediska žádoucí, aby se prostor dobročinnosti rozšiřoval, protože není správné pasivně se smiřovat s prrítomností lidské nouze a utrpení, ale zároveň by dobročinnost neměla narušovat fungování společenského celku. Ten by mohl být narušován přílišnou dobročinností, která porušováním principu zásluhovosti může demoralizovat a demotivovat jednotlivce, čímž se snižuje nutná společenská produktivita. Naopak absence dobročinnosti vede k vylučování širších skupin obyvatel ze společného prostoru, čímž se kvalita jejich životů může dostat pod lidskou úroveň. Obě krajnosti jsou v rozporu s principem humanismu, protože jeho smyslem není absolutizace hodnoty abstraktního člověka, ale ukládá nám morální povinnost usilovat o plnohodnotný a důstojný život každého jednotlivce. Jak objektivní ohrožení fungování společenského celku, tak subjektivní neochota pomoct druhým by tuto hodnotu negovaly. Dobrá vůle jako autonomní základ morální motivace jednání by se proto měla orientovat na plnění obou povinností, 
jak vůči celku, tak vůči každému jednotlivci. Je pak úlohou praktického rozumu nacházet mezi oběma povinnostmi přiměřenou rovnováhu.

\section{Literatura}

BIBLE. PÍSMO SVATÉ STARÉHO A NOVÉHO ZÁKONA (1991): Praha: Česká biblická společnost.

BLACKWELLOVA ENCYKLOPEDIE POLITICKÉHO MYŠLENÍ (1995): Přel. Jana Kuchtová. Brno: CDK, PROGLAS / JOTA.

FABRE, S. (2004): Good Samaritanism: A Matter of Justice. In: Seglow, J. (ed): The Ethics of Altruism. Frank Cass Publisher, 258-316.

FEBER, J. (2015): Pojem a idea demokracie (K otázce hodnotových základů současné společnosti). In: Annales Scientia Politica, 4 (1), 4-17.

GLUCHMAN, V. (1994): Úvod do etiky. Prešov: Universum.

GUNTHER, K. (1997): Co znamená: Každému to, co mu náleží? K novému odhalení distributivní spravedlnosti. In: Spor o spravedlnost. Přel. Alena Bakešová. Praha: Filozofia, 15-54.

HEYD, D. (1982): Superregation: Its Status in Ethical Theory. N.Y.: Cambridge Univ. press.

HODOVSKÝ, I. (1992): Úvod do etiky. Olomouc: FF UP.

KANT, I. (1996): The Metaphysics of Morals. Translated and edited by Mary Gregor; with an introduction by Roger J. Sullivan. Cambridge: Cambridge University Press.

KANT, I. (2004): Základy metafyziky mravov. Přel. Patrícia Elexová. Bratislava: Kalligram.

KOHLBERG, L. (1981): Essays on Moral Development. Vol. 1. The Philosophy of Moral Development: Moral stages and the Idea of Justice. N.Y.: Harper and Row.

MILL, J. S. (1843): Principles of Political Ekonomy. Works vol. V. London.

NODDINGS, N. (1984): Caring: a Femine Approach to Ethics and Moral Education. Los Angeles: Kalifornia Univ. Press.

PESCHKE, K. H. (2004): Křest'anská etika. Přel. Marek Skovajsa. Praha: Vyšehrad.

PETRUCIJOVÁ, J. (2010): Křižovatky antropologie - změny paradigmat. Díl 1. Počátky antropologických reflexí. Ostrava: OU.

RAWLS, J. (1971): A Theory of Justice. Cambridge, MA: Harvard University Press.

SCRUTON, R. (1996): Kant. Přel. Pavel Toman. Praha: Argo.

SWIFT, A. (2005): Politická filozofie: základní otázky moderní politologie. Přel. Denisa Šmejkalová. Praha: Portál.

VAJDA, J. (1995): Etika. Nitra: Enigma. 
doc. PhDr. Jaromír Feber, CSc.

Trnavská univerzita v Trnave

Filozofická fakulta

Katedra etiky a morálnej filozofie

Hornopotočná 23

918 43, Trnava

Slovenská republika

jaromir.feber@vsb.cz 